\title{
Entre a mágoa e o sonho... nas Estórias Abensonhadas de Mia Couto
}

Nataniel Ngomane*

* Docente da Universidade Eduardo Mondlane e Doutorando na Universidade de São Paulo. 
Mia Couto, ficcionista moçambicano já conhecido do público brasileiro ${ }^{1}$, usando uma linguagem que se tornou típica dos seus narradores e personagens, levanos, através das suas Estórias A bensonhadas, a percorrer os caminhos cinzentos, mas grávidos de sonhos, de um território sacudindo os resquícios de uma guerra civil: M oçambique. Ao dizer que essa linguagem se tornou típica, estou a considerar o facto de ela ter emigrado - na mão do ficcionista moçambicano (ou no seu bloco de notas?) - de uma real situação de uso empírico para a escrita ficcional, tornando-se, como tal, numa linguagem ficcionalizada.

$\mathrm{Na}$ verdade, trata-se de uma linguagem que, mais do que uma invenção ou criação linguístico-literária de Couto, corresponde às formas quotidianas de comunicação das camadas populares de moçambicanos que, tendo a língua portuguesa como língua segunda ${ }^{2}$, se sentem muitas vezes na contigência de se expressar - não sem dificuldades... mas expressando-se! - numa língua que, não sendo a sua, é a língua oficial da sua terra, além de ser uma língua de prestígio. (Lembrome, p.e., da polémica que se seguiu à publicação de Vozes Anoitecidas (1986) em Maputo, sobre o assunto). O u seja, formas linguísticas como "Tal i gual como descrevera Gigitinho..." (p.31), "Então, iniciou de descrever o mundo..."(p.33), "Na realmente, não valho as penas", "Me sinto ferrujado, Ananias" (p.38), "- Se um dia eu me escorregar... você me apanha, Virigílio Prego?", "Com a certeza, H ortência” (p.54), que encontramos na escrita ficcional de M ia Couto, estão associadas a essa

Veja-se, por exemplo, o texto de Ana Claudia da Silva, Mar me quer: a outra face da lua. In Via Atlântica, São Paulo: (2) : 265-269, 1999.

No sentido em que a sua aquisição se processa depois de se matizar uma língua materna outra (banta, no caso). 
outra maneira de falar a língua portuguesa em M oçambique, um falar saído dessas camadas onde um escritor atento como Mia Couto vai buscar, não só a matéria prima para a linguagem das suas estórias e os exemplares dos seus humildes personagens, mas também a inspiração para retrabalhar a língua como ele a retrabalha.

Errónea e reiteradamente, $\mathrm{M}$ ia Couto tem sido apontado como criador quase absoluto de novas palavras e expressões de língua portuguesa. Ora, se por um lado isso se nos afigura tarefa demasiada para uma só pessoa - mesmo tratandose de Mia Couto! -, por outro, não retira o mérito da sua criatividade, sobretudo, nos campos morfológico, sintáctico e semântico dessa língua. Expressões inseridas em frases como "F icara-se assim, desacertada, certa uma vez em que, já moça, foi atacada de convulsões" ( p.21), "A mão de G igito conduziu o desvi stado [cego] por tempos e idades", "Gigito Efraim estava como nunca esteve S. Tomé: via para não crer" (p.29), atestam o trabalho árduo do autor moçambicano ao nível do léxico, da morfologia, da sintaxe e da semântica da língua portuguesa, onde, funcionando com os mecanismos disponíveis na gramática dessa língua, instala um complexo sistema de neologismos e outro tipo de expressões, além de saborosíssimas pitadas de humor à moçambicana. Diria mesmo uma autêntica engenharia de (des) construção linguística, onde a competência literária do escritor se funde à linguística, produzindo uma obra agradável de se ler. "Trabalhou fundo: lá onde ia covando [fazer cova] já se desabria um escuro total" (p.66); "devagaroso", "cabecinhava"; "Voltamos antes de um agorinha ..." (p.13).

Sem dúvidas, autor altamente criativo (e por que não, também recreativo), Mia Couto deve, porém, a recriação de linguagem presente nos seus textos às populações urbanas e rurais de Moçambique, esses actores do quotidiano que, pese o facto de serem anónimos, se configuram como os autênticos falantes, fazedores da língua, e que a recriam, de facto, na dinâmica das suas vidas. N ote-se que é também de pedaços de vida desses actores sociais anónimos que se vão constituindo as vinte e seis Estórias Abensonhadas, e não só, do escritor moçambicano.

Escritas após um conflito armado que desvastou M oçambique por uns longos dezesseis anos - e que Mia Couto presenciou e viveu -, estas estórias não poderiam deixar de reflectir, de certo modo, a atenção que o escriba do Índico prestou a fenómenos como o dos deslocados de guerra, da desgraça que se abateu sobre inúmeras famílias, dos desmandos protagonizados pelas chamadas forças da lei, da injustiça, enfim... entre outros, todos eles gerados pela triste situação de guerra.

"As flores de Novi dade" e "O cego Estrel inho", p.e., são duas dessas estórias que nos levam de volta aos tempos de guerra, em que o simples troar das armas 
significava ou morte ou abandono de um espaço erguido a custa de muitos sacrifícios: o lar. Em qualquer dos casos, o resultado final é o desmembramento, muitas vezes irreversível, da família. E mesmo quando o amor à terra natal supera o medo das bombas e metralhadoras, impelindo à desobidiência da ordem de abandoná-la, como n' "O cachimbo de Felizbento", a morte aparece. Mas já não fulminante, como a que mata Gigito, o ex-guia do cego Estrelinho; mas serena e consciente, "promovida" a forma única e admissível de se apropriar, derradeiramente, do espaço sagrado que sempre é o nosso.

Contudo, e apesar de trágicas e dramáticas, estas estórias têm uma singela característica: os seus humildes personagens não se abstêm do sonho, armandose sempre do desejo de serem outros ${ }^{3}$, melhores, em melhores realidades. É assim que esses personagens temperam as estórias de $\mathrm{M}$ ia Couto de um realismo fantástico e, não poucas vezes, maravilhoso, alternativa, quanto a nós, salutar a uma realidade insana e caótica.

De facto, e como diz o seu autor, são estórias que surgem entre as margens da mágoa e da esperança. Da mágoa, por toda a roupagem escatologizante de que se reveste o fenómeno guerra, com toda a sua violência calamitosa; da esperança, por outro, porquanto o sonho, sempre presente em cada episódio, é o próprio pulsar do porvir, esse lugar nenhures onde se pretende que se sarem as feridas abertas pelo conflito. I maginário embora, o universo que nos é apresentado nestas E stóri as A bensonhadas não dista muito da crua realidade deixada pela guerra civil em Moçambique, desde o reaprender da vida e das práticas tradicionais - as quais também não escaparam à fúria das armas -, passando pelo resgate dos mortos, seres sagrados reiteradamente simbolizados pelos espíritos.

A propósito, é sugestiva a estória do avô e do neto, "Nas águas do tempo", na qual a passagem do testemunho de geração para geração não só reflecte esse reaprendizado da vida e dos costumes, como retrata de tão perto a ainda viva cultura da oralidade, onde a palavra do mais velho, o avô, é a escola: não só do gesto e dos profundos segredos do saber, mas, e sobretudo, do culto aos antepassados, cuja força e energia está sempre presente. I magem que tem vindo a acompanhar os escritos de Mia Couto, a relação mais velho/mais novo, com todos os segredos da secular transmissão do saber, chega a sugerir de forma vigorosa um realismo maravilhoso tipicamente africano em "Chuva: a abensonhada".

Sinal de esperança para muitos povos, a chuva, milenarmente tida como purificadora, aparece nesta estória também como "recado dos espíritos" (p.59) em resposta às preces dos viventes: “a chuva está a acontecer devido das rezas,

$\mathrm{Na}$ verdade, estou a parafrasear o próprio Mia no seu “Texto de abertura” a Vozes Anoitecidas, 2a E dição (Lisboa: Caminho, 1987, p.19). 
cerimónias oferecidas aos antepassados." (p.60) E tal como milhares de moçambicanos acreditaram em 1992, quando o Acordo Geral de Paz pôs fim à guerra civil em Moçambique, a Tia Tristereza também acredita que em todo o M oçambique as chuvas já podem voltar a cair porque a guerra está a parar: "Sim, agora já as chuvas podem recomeçar. Todos estes anos, os deuses nos castigaram com a seca". (p.60)

Fusão do real e do maravilhoso, na qual o fim da guerra se desdobra num retomar das tradições pisoteadas pelas forças beligerantes e no sonho alcançável de tempos melhores, estas Estórias Abensonhadas de Mia Couto são o próprio quadro do quotidiano imaginário moçambicano.

\section{R eferências Bibliográficas}

COUTO, Mia. Estórias Abensonhadas. 2ª E dição. Lisboa: Caminho, 1987.

COUTO, Mia. Estórias Abensonhadas. Rio de J aneiro: Nova F ronteira, 1986. 
